ISSN : 2337-3067

E-Jurnal Ekonomi dan Bisnis Universitas Udayana 7.6 (2018): 1529-1556

\title{
Lingkungan Kerja dan Locus of Control Sebagai Pemoderasi Pengaruh Penggunaan Teknologi Informasi Pada Keandalan Pelaporan Keuangan Pemerintah Daerah
}

\author{
Rai Dwi Andayani $\mathbf{W}^{1}$ \\ A.A.G.P Widanaputra ${ }^{2}$ \\ Ida Bagus Putra Astika ${ }^{3}$
${ }^{1,2,3}$ Fakultas Ekonomi dan Bisnis Universitas Udayana (Unud), Bali, Indonesia
e-mail: dwiandayani63@yahoo.com

\begin{abstract}
ABSTRAK
Penelitian ini dilatarbelakangi semakin meningkatnya penggunaan teknologi maka diharapkan pelaporan keuangan yang dihasilkan semakin handal, hal ini berkaitan dengan semakin meningkatnya tuntutan masyarakat terhadap penyelenggaraan pemerintahan yang baik (good governance government), telah mendorong pemerintah pusat dan pemerintah daerah untuk menerapkan akuntabilitas publik. Penelitian ini bertujuan untuk mendapatkan bukti empiris bahwa lingkungan kerja dan internal locus of control mampu memperkuat pengaruh penggunaan teknologi informasi pada keandalan pelaporan keuangan pemerintah daerah. Data penelitian ini dikumpulkan melalui metode survey dengan teknik kuesioner dan dianalisis dengan analisis regresi moderasi (MRA/ Moderated Regression Analysis). Sampel penelitian diambil menggunakan sampel jenuh dengan unit analisis seorang individu pada masing-masing Bendahara Organisasi Perangkat Daerah (OPD). Hasil analisis menunjukkan bahwa lingkungan kerja dan internal locus of control memperkuat pengaruh penggunaan teknologi informasi pada keandalan pelaporan keuangan pemerintah daerah. Hasil empiris ini memperkuat teori Technology Acceptance Model (TAM) dan teori atribusi sebagai landasan untuk mempelajari dan memahami perilaku pemakai pengguna teknologi informasi baik perilaku yang disebabkan secara internal ataupun eksternal.

Kata Kunci : Lingkungan Kerja, Internal Locus of Control, Penggunaan Teknologi Informasi, dan Keandalan Pelaporan Keuangan Pemerintah Daerah.
\end{abstract}

\begin{abstract}
This study is motivated by the increasing use of technology, it is expected that financial reporting will be more reliable, it is related to the increasing demand of the society towards good governance government, has encouraged the central government and local government to implement public accountability. This study aims to obtain empirical evidence that the work environment and internal locus of control able to strengthen the influence of the use of information technology on the reliability of local government financial reporting.Data of this research were collected through survey method with questionnaire technique and analyzed by moderation regression analysis (MRA / Moderated Regression Analysis). The sample was taken using a saturated sample with an individual's analysis unit at each of the Regional Device Organization (OPD).The results of the analysis show that the work environment and internal locus of control strengthen the influence of the use of information technology on the reliability of local government financial reporting. These empirical results reinforce the theory of Technology Acceptance Model (TAM) and attribution theory as a foundation for studying and understanding user behavior of information technology users either internally or externally caused behavior.
\end{abstract}

Keywords : Work Environment, Internal Locus of Control, Use of Information Technology, and Reliability of Local Government Financial Reporting. 


\section{PENDAHULUAN}

Meningkatnya tuntutan dari masyarakat pada pemerintahan yang baik (good governance government), semakin mendorong pemerintah pusat dan pemerintah daerah untuk menerapkan akuntabilitas publik di Indonesia. Akuntabilitas finansial khususnya di daerah, pemerintah daerah bertanggung jawab untuk mempublikasikan laporan keuangan kepada stakeholder. Sebagian besar orang mengandalkan informasi dalam laporan keuangan yang dipublikasikan oleh pemerintah daerah sebagai dasar untuk pengambilan keputusan, dimana pihak - pihak pengguna laporan keuangan pemerintah antara lain : masyarakat, para wakil rakyat, lembaga pengawas, lembaga pemeriksa, pihak yang memberi atau berperan dalam proses donasi, investasi, pinjaman dan pemerintah sendiri (Warsito et al., 2008).

Seluruh informasi yang bermanfaat bagi para pemakai adalah informasi yang mempunyai nilai dan sangat berguna apabila informasi tersebut dapat mendukung pengambilan keputusan dan dapat mencapai tujuan suatu organisasi. Setiap pemerintah daerah wajib memperhatikan dan memberikan informasi yang disajikan dalam laporan keuangan untuk kegiatan perencanaan, pengendalian, dan pengambilan keputusan. Informasi akuntansi yang terdapat di dalam Laporan Keuangan Pemerintah Daerah (LKPD) wajib memiliki beberapa karakteristik kualitatif yang disyaratkan oleh pemerintah daerah. Karakteristik kualitatif laporan keuangan adalah setiap ukuran-ukuran normatif yang perlu diwujudkan dan direalisasikan dalam informasi akuntansi sehingga dapat memenuhi tujuan organisasi. 
Keandalan pelaporan keuangan diukur berdasarkan transaksi serta peristiwa lainnya yang seharusnya disajikan secara wajar dapat disajikan dengan jujur dalam laporan keuangan, neraca disajikan, laporan realisasi anggaran atau laporan perhitungan APBD disajikan, catatan atas laporan keuangan disajikan, informasi yang disajikan dalam laporan keuangan dapat diuji, rekonsiliasi dilakukan secara periodik antara catatan akuntansi dengan catatan bank atau catatan pihak eksternal yang membutuhkan konfirmasi atau rekonsiliasi, dan informasi diarahkan pada kebutuhan umum dan tidak berpihak pada kebutuhan pihak tertentu. (Peraturan Pemerintah Nomor 71 Tahun 2010 tentang Standar Akuntansi Pemerintahan Lampiran II, 2010). Didukung oleh riset yang dilakukan oleh Anisatin (2015), Shinta (2014), Celviana (2010), dan Febriady (2013) menemukan bahwa pemanfaatan teknologi informasi berpengaruh positif signifikan terhadap keterandalan pelaporan keuangan pemerintah daerah. Sedangkan penelitian yang dilakukan oleh Dian (2014), Gita (2014), dan Mudrika (2015) menemukan bahwa pemanfaatan teknologi informasi tidak berpengaruh positif signifikan terhadap keterandalan pelaporan keuangan pemerintah daerah.

Fenomena yang terjadi pada pelaporan keuangan pemerintahan daerah merupakan sesuatu hal yang sangat menarik untuk diteliti dan dikaji kembali. Di setiap daerah pada nyatanya masih banyak disajikan data yang tidak sesuai dengan kenyataan yang ada dan bahkan adanya kekeliruan yang masih ditemukan. Temuan pemeriksaan BPK dalam semester II tahun 2011 menyatakan bahwa dari 516 LKPD, 
BPK memberikan opini wajar tanpa pengecualian hanya 34 LKPD saja. Hasil pemeriksaan BPK yang dilaporkan IHPS II tahun 2011 juga mengungkapkan kerugian negara pada tahun 2010 sebesar Rp 20,25 triliun akibat kelemahan sistem pengendalian intern dan ketidakpatuhan daerah dalam menjalankan peraturan perundang-undangan (BPK RI). Hasil evaluasi atas 516 LKPD, terdapat 4.178 kasus kelemahan sistem pengendalian intern (SPI) yang meliputi kelemahan sistem pengendalian akuntansi dan pelaporan. Pada akhirnya jika sistem pengendalian intern pada instansi pemerintah belum dilaksanakan secara optimal, hal ini mungkin memiliki pengaruh terhadap keandalan pelaporan keuangan pemerintah.

Pelaksanaan pengenalan penggunaan teknologi merupakan hal yang diharapkan dapat mendukung pembangunan berkelanjutan di Kabupaten Badung. Teknologi informasi dipandang strategis dalam mewujudkan sistem aplikasi teknologi dalam membangun sistem yang terintegrasi dalam pembangunan pada berbagai bidang dan lintas sektor. Bidang Pengkajian Kebijakan Teknologi (BPPT) menyambut baik komitmen Pemkab Badung menerapkan aplikasi Teknologi Informasi dan Komunikasi (TIK). Pentingnya peran TIK dalam penyelenggaraan pemerintahan di era digital yang berkembang pesat saat ini. Terutama dalam pengelolaan pelaoran keuangan, pengelolaan informasi serta sistem manajemen dan proses kerja instansi pemerintahan. Pendapatan Asli Daerah (PAD) Kabupaten Badung sangat tinggi sehingga membutuhkan user penggunaan teknologi yang mampu menghasilan pelaporan keuangan daerah yang andal dan valid. 
Model Technology Acceptance Model (TAM) merupakan hal yang digunakan pada penerapan konteks teknologi, dimana TAM merupakan sistem informasi yang mampu mempermudah kinerja seseorang atau organisasi, serta meringankan dalam menyelesaikan pekerjaan (Dasgupta, 2002). Menurut Kumar dan Anderson (1990) dalam McCoy (2002), perkembangan dunia bisnis menjadikan studi mengenai penggunaan teknologi informasi juga semakin bertambah maju seiring perkembangan jaman. Konsep TAM dikembangkan oleh Davis (1989) yang memaparkan bahwa teori ini sebagai landasan untuk mempelajari dan memahami perilaku pemakai dalam menerima dan menggunakan sistem informasi (Handayani, 2007). Perluasan konsep TAM diharapkan akan mempermudah dalam memprediksi sikap dan penerimaan seseorang terhadap teknologi dan dapat menyampaikan informasi yang mendasar mengenai faktor-faktor yang menjadi pendorong sikap individu tersebut (Lee, 2010).

Peran dari lingkungan kerja dan internal locus of control selaras dengan teori atribusi, teori ini menyatakan bahwa usaha ketika individu-individu mengamati perilaku untuk menentukan apakah hal ini disebabkan secara internal atau eksternal. Dalam mengamati perilaku seseorang, dilihat dari faktor eksternal yaitu lingkungan kerja.

Peran dari penggunaan teknologi informasi terkait dengan keandalan pelaporan keuangan pemerintah daerah, maka digunakan locus of control untuk mengukur seberapa besar keahlian tingkat pengguna teknologi informasi dan kualitas SDM. Selain memiliki keahlian yang tinggi, seorang juga dituntut untuk mempunyai 
sikap independensi yang tinggi (Yoga, 2016). Adapun pembawaan internal locus of control yaitu mereka percaya bahwa hasil dari suatu aktivitas sangat tergantung pada usaha dan kerja keras orang itu sendiri. Individu harus mempunyai kesatuan locus of control yang baik untuk dapat melaksanakan tugas dengan baik karena hal tersebut mempunyai pengaruh dalam menghindari perilaku disfungsional. Semakin mereka percaya bahwa hasil dari suatu pekerjaan mereka akan lebih mudah dengan menggunakan teknologi informasi, maka pelaporan keuangan yg dihasilkan akan semakin andal. Didukung oleh riset yang dilakukan oleh Mahdy dan Imam (2012) menunjukkan adanya pengaruh locus of control terhadap kinerja auditor internal. Sistem pengendalian intern dapat memperkuat pengaruh locus of control terhadap nilai informasi laporan keuangan. Penelitian yang dilakukan oleh Pranata (2017) dan Sayputri (2017) juga menunjukkan internallocus of control mampu untuk memperkuat atau memoderasi hubungan antara penggunaan teknologi informasi pada keterandalan pelaporan keuangan pemerintah daerah.

Peran dari penggunaan teknologi informasi terkait keandalan pelaporan keuangan pemerintah daerah, maka digunakan faktor lain seperti lingkungan kerja yang nyaman dan aman akan membuat pegawai juga ikut merasa nyaman bekerja sehingga tugas yang dilakukan oleh para pegawai juga baik dan itu mempengaruhi cara bekerja pegawai. Jika lingkungan kerja tidak baik, maka akan timbul perselisihan antar pegawai jika tidak adanya pengendalian intern antara satu pihak dengan pihak lainnya. Semakin baik lingkungan kerja, maka akan semakin 
mendukung penggunaan teknologi dalam menghasilkan pelaporan keuangan yang andal dan valid. Lingkungan kerja dapat dijadikan variabel moderasi karena lingkungan kerja yang baik secara fisik maupun non fisik sangat diperlukan oleh karyawan untuk bekerja senyaman mungkin, tetapi jika lingkungan sekitar tidak memadai atau buruk, maka karyawan tidak akan memiliki kepuasan dalam menyelesaikan pekerjaan (Anas, 2013). Sehingga lingkungan kerja dapat memperkuat pengaruh penggunaan teknologi informasi pada keterandalan pelaporan keuangan pemerintah daerah. Penelitian Ridolof (2014) dan Kristi (2013) juga menunjukkanbahwalingkungan kerja sebagai variabel moderasi mampu memperkuat pengaruh penggunaan teknologi informasi pada keandalan pelaporan keuangan pemerintah daerah.

Dibandingkan dengan penelitian sebelumnya, penelitian ini menggunakan variabel yang berbeda dari penelitian sebelumnya karena menggunakan dua variabel pemoderasi, yaitu lingkungan kerja dan internal locus of control, selain itu sampel yang digunakan bukan fresh graduate yang baru menjadi pegawai instansi keuangan lagi melainkan seluruh pegawai instansi yang merupakan pegawai pembuat laporan keuangan serta pernah mempraktekan bagaimana melaporkan laporan keuangan atau suatu informasi akuntansi yang berkualitas. Beberapa penelitian terdahulu masih terdapat ketidak konsistenan hasil penelitian, sehingga dilakukannya penelitian kembali untuk mengetahui dan mengkaji lebih dalam mengenai lingkungan kerja dan 
Rai Dwi Andayani W, A.A.G.P Widanaputra, dan Ida Bagus Putra Astika. Lingkungan Kerja...

locus of control memoderasi pengaruh penggunaan teknologi informasi pada keandalan pelaporan keuangan pemerintah daerah.

Semakin baik lingkungan kerja, maka akan mendukung penggunaan teknologi dalam menghasilkan pelaporan keuangan yang andal dan valid. Dalam teori atribusi untuk mengamati perilaku seseorang, dapat dilihat dari faktoreksternal yaitu lingkungan kerja. Perilaku secara eksternal dilihat sebagai hasil dari sebab-sebab luar yaitu terpaksa berperilaku karena situasi (Robbins, 1996). Dalam setiap keadaan maupun situasi yang dialami karyawan dalam bekerja harus diperhatikan sebaik mungkin agar karyawan merasa puas dan nyaman dalam bekerja. Davis et al. (1989) mengembangkan TAM untuk meneliti faktor-faktor determinan dari penggunaan sistem informasi oleh pengguna. Hasil penelitian ini menunjukan penggunaan sistem informasi dipengaruhi oleh minat pemanfaatan sistem informasi, yang mana minat tersebut dipengaruhi oleh persepsi tentang kegunaan teknologi dan persepsi tentang kemudahan penggunaan teknologi. Hal inimengindikasikan bahwa tinggi rendahnya kemampuan karyawan untuk beradaptasi dengan lingkungan kerja berdampak pada persepsi manfaat dari pemanfaatan penggunaan teknologi itu dalam menghasilkan pelaporan keuangan yang andal.

Dalam teori atribusi untuk mengamati perilaku seseorang, dapat dilihat dari faktoreksternal yaitu lingkungan kerja. Perilaku secara eksternal dilihat sebagai hasil dari sebab-sebab luar yaitu terpaksa berperilaku karena situasi (Robbins, 1996). Oleh karena itu keadaan maupun situasi yang ada di sekitar karyawan dalam bekerja harus 
dijaga sebaik mungkin agar karyawan merasa nyaman dalam bekerja. Penelitian Ridolof (2014) dan Kristi (2013) juga menunjukkanbahwalingkungan kerja sebagai variabel moderasi mampu memperkuat pengaruh penggunaan teknologi informasi pada keterandalan pelaporan keuangan pemerintah daerah.

H1: Lingkungan kerja memperkuat pengaruh penggunaan teknologi informasi pada keandalan pelaporan keuangan pemerintah daerah.

Semakin mereka percaya bahwa hasil dari suatu pekerjaan mereka akan lebih mudah dengan menggunakan teknologi informasi, maka pelaporan keuangan yg dihasilkan akan semakin andal. Teori TAM menyatakan bahwa segala niat seseorang dalam menggunakan sistem atau teknologi ditentukan oleh dua faktor, yaitu persepsi kemanfaatan adalah suatu tingkat kepercayaan individu dalam penggunaan teknologi akan mampu meningkatkan kinerjanya, dan persepsi kemudahan penggunaan adalah tingkat kepercayaan individu bahwa menggunakan teknologi akan mempermudah dalam menyelesaikan pekerjaan dengan usahanya sendiri (Venkatesh dan Davis, 2000).

Teori atribusi membahas mengenai faktor-faktor yang mengakibatkan suatu hal terjadi, apakah hal tersebut terjadi karena faktor internal atau eksternal. Pada penelitian yang dilakukan ini akan dikaji mengenai internal locus of control, apakah faktor tersebut dapat berpengaruh terhadap tekanan kerja, kepuasan kerja dan kinerja karyawan. Keterkaitan antara teori atribusi dengan penelitian ini adalah sama-sama mengamati apakah tekanan kerja, kepuasan kerja dan kinerja karyawan lebih banyak 
dipengaruhi oleh faktor eksternal atau internal.Gustati (2012) menyimpulkan bahwa secara simultan, internal locus of control dan eksternal locus of control berpengaruh signifikan terhadap penerimaan perilaku disfungsional. Individu harus mempunyai kesatuan locus of control yang baik untuk dapat melaksanakan tugas dengan baik, karena hal ini dapat menghindari perilaku disfungsional (Yoga, 2016).Penelitian yang dilakukan oleh Pranata (2017) dan Sayputri (2017) juga menunjukkan internallocus of control mampu untuk memperkuat atau memoderasi hubungan antara penggunaan teknologi informasi pada keandalan pelaporan keuangan pemerintah daerah. Berdasarkan landasan teori dan dasar pemikiran diatas, maka dirumuskan hipotesis sebagai berikut.

H2: Internal locus of control memperkuat pengaruh penggunaan teknologi informasi pada keandalan pelaporan keuangan pemerintah daerah.

\section{METODE PENELITIAN}

Penelitian ini menggunakan data kuantiatif.Lokasi penelitian yaitu di seluruh Organisasi Perangkat Daerah (OPD) di Kabupaten Badung, karena di OPD Kabupaten Badung memiliki banyak OPD yang lengkap di sini. Waktu penelitian adalah tahun 2017. Variabel Moderasi dalam penelitian ini yaitu lingkungan kerja dan internal locus of control.Data penelitian ini dikumpulkan melalui metode survey dengan teknik kuesioner. Metode pengumpulan data yang digunakan dalam penelitian ini adalah metode survey dengan teknik kuesioner. Pertanyaan dalam kuisioner untuk masing-masing variabel dalam penelitian diukur dengan 
menggunakan skala likert. Skala likert adalah suatu skala yang digunakan untuk mengukur sikap, pendapat, persepsi seseorang atau sekelompok orang tentang fenomena sosial. Semua pertanyaan yang digunakan untuk mengukur variabelvariabel dalam penelitian ini dapat dilihat dalam lampiran kuesioner. Sampel penelitian diambil menggunakan sampel jenuh dengan unit analisis seorang individu pada masing-masing Bendahara Organisasi Perangkat Daerah (OPD). Jumlah sampel dalam penelitian ini adalah 110 bendahara. Berdasarkan kuesioner yang disebar, kuesioner yang digunakan dalam penelitian ini sebanyak 89 kuesioner.Definisi operasional variabel merupakan suatu definisi yang dinyatakan dalam bentuk istilah yang diuji secara spesifik atau dengan pengukuran tertentu (Ikhsan, 2008:62). Definisi operasional variabel pada penelitian ini yaitu:

1. Keandalan pelaporan keuangan pemerintah daerah (Y) merupakan kemampuan informasi untuk memberikan keyakinan bahwa informasi tersebut benar atau valid. (PP No. 24 Tahun 2005).

2. Penggunaan Teknologi Informasi (X1), yaitu mengukur seberapa besar keahlian tingkat pengguna teknologi informasi dan kualitas SDM.

3. Lingkungan Kerja (X2) yaitu segala sesuatu yang ada di sekitar para pekerja yang dapat mempengaruhi dirinya dalam menjalankan tugas-tugas yang diembannya.

4. Internal Locus Of Control (X3) yaitu mereka percaya bahwa hasil dari suatu aktivitas sangat tergantung pada usaha dan kerja keras orang itu sendiri. 
Berikut ini merupakan konsep dari penelitian ini adalah sebagai berikut:

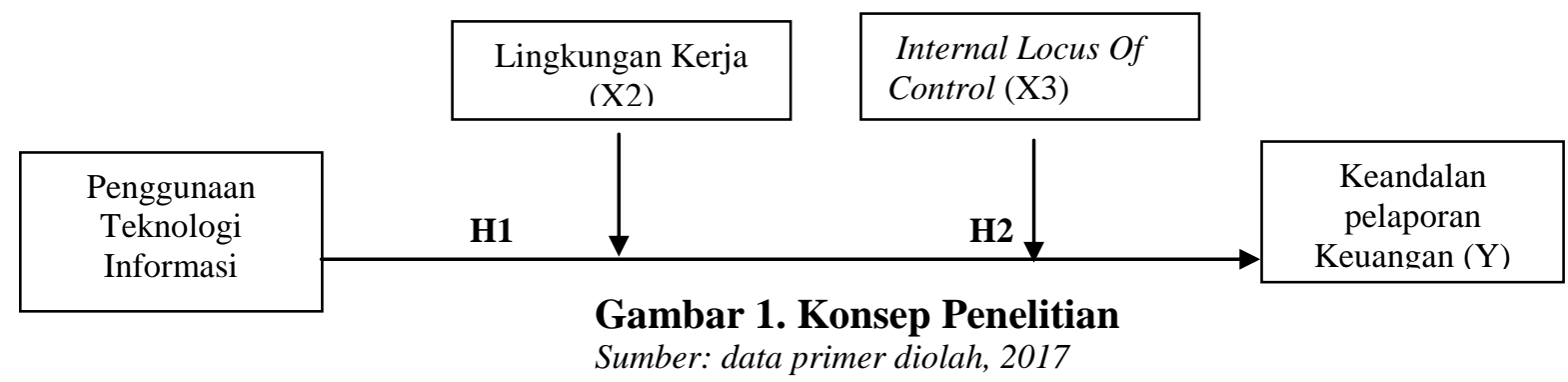

Uji analisis koefisien regresi akan menggunakan uji Moderating Regression Analysis (MRA). Moderating Regression Analysis (MRA) merupakan aplikasi khusus regresi linear berganda, dimana dalam persamaan regresinya mengandung unsur interaksi (perkalian dua atau lebih variabel independen). Uji interaksi ini digunakan untuk mengetahui sejauh mana interaksi variabel lingkungan kerja dan internal locus of control dapat memengaruhi penggunaan teknologi informasi pada keandalan pelaporan keuangan. Model persamaan Moderating Regression Analysis (MRA) yang digunakan adalah sebagai berikut.

$\mathrm{y}=a+b 1 X 1+b 2 X 2+b 3 X 3+b 4 X 1 * X 2+b 5 X 1 * X 3+\varepsilon$.

Keterangan:

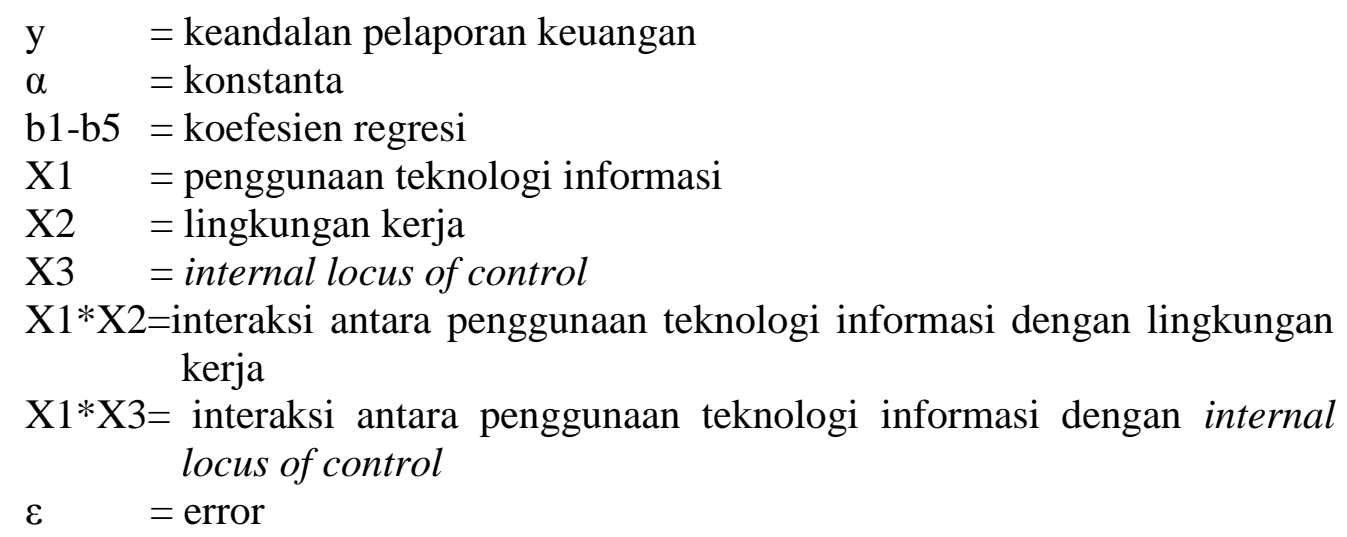


Sebelum dilakukan pengujian Moderated Regression Analysis (MRA), terlebih dahulu dilakukan pengujiam instrumen yang terdiri dari uji validitas dan reliabilitas instrumen, analisis statistik deskriptif dan uji asumsi klasik yang terdiri atas uji normalitas, uji multikolinieritas dan uji heteroskedastisitas.

\section{HASIL DAN PEMBAHASAN}

Hasil Penelitian ini diperoleh dari pengumpulan data berupa kuesioner dengan responden berdasarkan jabatan bendahara penerimaan dan pengeluaran di seluruh Organisasi Perangkat Daerah (OPD) yang berada di Kabupaten Badung. Jumlah sampel dalam penelitian ini adalah 110 bendahara. Berdasarkan kuesioner yang disebar, kuesioner yang digunakan dalam penelitian ini sebanyak 89 kuesioner. Adanya 18 kuesioner yang tidak kembali karena adanya mutasi pegawai dan adanya tugas pendidikan diluar kota pada saat penyebaran kesioner.

\section{Tabel 1}

Tingkat Pengembalian Kuesioner

\begin{tabular}{|l|c|c|}
\hline \multicolumn{1}{|c|}{ Keterangan } & Jumlah & Persentase \\
\hline & & $100 \%$ \\
Kuesioner yang disebar & 110 & $16 \%$ \\
\hline Kuesioner yang tidak kembali & 18 & $84 \%$ \\
\hline Kuesioner yang kembali & 92 & $3 \%$ \\
\hline kuesiner yang tidak lengkap & 3 & $81 \%$ \\
\hline Kuesioner yang dapat digunakan & 89 & \\
\hline Tingkat pengembalian: 92/110 x 100\% $=84 \%$ & \\
\hline Tingkat pengembalian yang digunakan : 89/110 x $100 \%=81 \%$ & \\
\hline
\end{tabular}

\section{Analisis Statistik Deskriptif}

Statistik deskriptif adalah statistik yang digunakan untuk menganalisa data dengan cara mendeskripsikan atau menggambarkan data yang telah terkumpul 
Rai Dwi Andayani W, A.A.G.P Widanaputra, dan Ida Bagus Putra Astika. Lingkungan Kerja...

sebagaimana adanya tanpa bermaksud membuat kesimpulan yang berlaku untuk umum atau generalisasi (Sugiyono, 2014: 142). Statistik deskriptif disajikan untuk memberikan gambaran mengenai karakteristik variabel-variabel penelitian, antara lain nilai minimum, maximum, mean dan standard deviation.

\section{Tabel 2}

Statistik Deskriptif

\begin{tabular}{lccccc}
\hline & N & Minimum & Maximum & Mean & Std. Deviation \\
\hline X1 & 89 & 25,00 & 40,00 & 34,2135 & 2,96752 \\
X2 & 89 & 101,00 & 150,00 & 124,1798 & 9,59825 \\
X3 & 89 & 46,00 & 81,00 & 66,2921 & 6,79104 \\
Y & 89 & 26,00 & 40,00 & 34,3371 & 2,69656 \\
X1*X2 & 89 & 2550,00 & 6000,00 & 4267,4494 & 618,97792 \\
X1*X3 & 89 & 1378,00 & 2997,00 & 2277,1798 & 356,68134 \\
$\quad$ Valid N (listwise) & 89 & & & & \\
\hline
\end{tabular}

Sumber: Data diolah, 2017

Berikut pemaparan statistik deskriptif :

Variabel penggunaan teknologi informasi (X1) menunjukkan bahwa nilai minimum dari jawaban responden sebesar 25 , nilai maximum sebesar 40 dan nilai mean sebesar 34,213 dengan standard deviation sebesar 2,96752. Dengan demikian responden dalam penelitian ini memiliki pemahaman yang tinggi terhadap penggunaan teknologi informasi. Dengan kriteria tinggi $\geq 34$ sampai dengan 37 .

Variabel lingkungan kerja (X2) menunjukkan bahwa nilai minimum dari jawaban responden sebesar 101, nilai maximum sebesar 150 dan nilai mean sebesar 124,1798 dengan standard deviation sebesar 9,59825. Dengan demikian responden dalam penelitian ini memiliki pemahaman yang cukup tinggi terhadap lingkungan kerja. Dengan kriteria cukup tinggi $\geq 120,6$ sampai dengan 130,4. 
Variabel internal locus of control (X3) menunjukkan bahwa nilai minimum dari jawaban responden sebesar 46, nilai maximum sebesar 81 dan nilai mean sebesar 66,2921 dengan standard deviation sebesar 6,79104. Dengan demikian responden dalam penelitian ini memiliki pemahaman yang cukup tinggi terhadap internal locus of control. Dengan kriteria cukup tinggi $\geq 60$ sampai dengan 67.

Variabel keandalan pelaporan keuangan pemerintah daerah (Y) menunjukkan bahwa nilai minimum dari jawaban responden sebesar 26, nilai maximum sebesar 40 dan nilai mean sebesar 34,3371 dengan standard deviation sebesar 2,69656. Dengan demikian responden dalam penelitian ini memiliki pemahaman yang cukup tinggi terhadap keandalan pelaporan keuangan pemerintah daerah. Dengan kriteria cukup tinggi $\geq 31,6$ sampai dengan 34,4 .

\section{Uji Instrumen}

Uji Validitas digunakan untuk mengukur sah atau valid tidaknya suatu kuesioner (Ghozali, 2009:49). Sebuah kuesioner dikatakan valid apabila mampu mengukur apa yang seharusnya diukur (Sugiyono, 2013:172). Uji validitas dilakukan dengan menghitung korelasi antara skor masing-masing butir pernyataan dengan total skor sehingga didapat nilai Pearson Correlation. Jika korelasi antara masing-masing skor butir pernyataan terhadap total skor butir-butir pernyataan menunjukkan hasil yang signifikan maka masing-masing butir pernyataan tersebut dikatakan valid (Ghozali, 2009:51). Syarat minimum suatu kuesioner yang memenuhi validitas adalah jika korelasi antara skor butir dengan skor total tersebut positif dan lebih besar 
Rai Dwi Andayani W, A.A.G.P Widanaputra, dan Ida Bagus Putra Astika. Lingkungan Kerja...

dari 0,3 (Sugiyono, 2013: 178). Uji validitas dilakukan dengan bantuan fasilitas program Statistical Package for Social Science (SPSS).

Sugiyono (2013:184), instrumen yang reliabel adalah instrumen yang digunakan beberapa kali untuk mengukur objek yang sama akan menghasilkan data yang sama. Reliabilitas adalah derajat ketepatan, ketelitian atau keakuratan yang ditunjukkan oleh instrumen pengukuran dimana pengujiannya dapat dilakukan secara internal, yaitu pengujian dengan menganalisis konsistensi butir-butir yang ada. Ghozali (2009:46) variabel dikatakan reliabel jika nilai Cronbach Alpha> 0,6. Pengujian reliabilitas pada penelitian ini menggunakan metode Cronbach Alpha melalui bantuan program Statistical Package for Social Science (SPSS).

Tabel 3

Hasil Uji Reliabilitas

\begin{tabular}{|l|c|c|c|}
\hline \multicolumn{1}{|c|}{ Variabel } & $\begin{array}{c}\text { Jumlah } \\
\text { Item } \\
\text { Pertanyaan }\end{array}$ & $\begin{array}{c}\text { Koefisien Alpha } \\
\text { Cronbach }\end{array}$ & Keterangan \\
\hline X1 (Penggunaan Teknologi Informasi) & 8 & 0,813 & Reliabel \\
\hline X2 ( Lingkungan Kerja) & 30 & 0,910 & Reliabel \\
\hline X3 (Internal Locus Of Control) & 17 & 0,866 & Reliabel \\
\hline $\begin{array}{l}\text { Y (Keterandalan Pelaporan Keuangan } \\
\text { Pemerintah Daerah) }\end{array}$ & 8 & 0,802 & Reliabel \\
\hline
\end{tabular}

Sumber: Data diolah, 2017

\section{Uji Asumsi Klasik}

Uji normalitas bertujuan untuk menguji apakah model regresi variabel residual dari persamaan regresi mempunyai distribusi normal atau tidak. Model regresi yang baik adalah berdistribusi normal atau mendekati normal. Uji normalitas 
nilai residual dalam penelitian ini dilakukan dengan menggunakan statistik Kolmogorov-Smirnov $(K-S)$.Residual berdistribusi normal apabila tingkat signifikansinya menunjukkan nilai yang lebih besar dari 0,05.Tabel 3 menunjukkan nilai Asymp. Sig. (2-tailed) untuk masing- masing model regresi yaitu sebesar 0,199> dari 0,05. Hal ini berarti bahwa model regresi berdistribusi normal.

\section{Tabel 4}

\section{Hasil Uji Normalitas}

\begin{tabular}{ccc}
\hline No $\quad$ Persamaan Regresi & Asymp.Sig ( 2-tiled) \\
\hline $1 \quad \mathrm{y}=\alpha+\mathrm{b} 1 \mathrm{X} 1+\mathrm{b} 2 \mathrm{X} 2+\mathrm{b} 3 \mathrm{X} 3+\mathrm{b} 4 \mathrm{X} 1 * \mathrm{X} 2+\mathrm{b} 5 \mathrm{X} 1 * \mathrm{X} 3+\varepsilon$ & 0,199 \\
\hline \multicolumn{2}{c}{ Sumber: Data diolah, 2017}
\end{tabular}

\section{Uji Heteroskedastisitas}

Tabel 5

Hasil Uji Heteroskedastisitas

\begin{tabular}{crr}
\hline Variabel & $\mathrm{t}$ & Sig. \\
\hline $\mathrm{X} 1$ & 0,901 & 0,370 \\
$\mathrm{X} 2$ & $-1,872$ & 0,065 \\
$\mathrm{X} 3$ & $-0,464$ & 0,644 \\
$\mathrm{X} 1 * \mathrm{X} 2$ & $-0,220$ & 0,826 \\
$\mathrm{X} 1 * \mathrm{X} 3$ & 0,719 & 0,474 \\
\hline Sumber: Data diolah, 2017 & &
\end{tabular}

Sumber: Data diolah, 2017

Tabel 5 menunjukkan nilai signifikansi dari masing-masing variabel pada model regresi lebih besar dari 0,05 . Hal ini berarti bahwa model regresi yang dibuat tidak terjadi gejala heteroskedastisitas, sehingga layak digunakan untuk memprediksi. 


\section{Moderated Regression Analysis (MRA)}

\section{Tabel 6}

Hasil Analisis Regresi Moderasi (MRA)

\begin{tabular}{|c|c|c|c|c|c|c|c|}
\hline \multirow{2}{*}{$\begin{array}{c}\text { Variabel } \\
\text { Terikat }\end{array}$} & \multicolumn{7}{|c|}{ Standar } \\
\hline & Variabel Bebas & & $\mathrm{B}$ & Error & $\mathrm{t}$ & & Sig. \\
\hline Keandalan & $\mathrm{X} 1$ & & 7,109 & 0,587 & 12,105 & & 0,000 \\
\hline Pelaporan & $\mathrm{X} 2$ & & 0,315 & 0,116 & 2,727 & & 0,008 \\
\hline \multirow[t]{5}{*}{ Keuangan } & $\mathrm{X} 3$ & & 3,153 & 0,339 & 9,306 & & 0,000 \\
\hline & $\mathrm{X} 1 * \mathrm{X} 2$ & & 0,012 & 0,001 & 8,537 & & 0,000 \\
\hline & $\mathrm{X} 1 * \mathrm{X} 3$ & & 0,095 & 0,009 & 10,866 & & 0,000 \\
\hline & Constant & $=$ & 256,789 & & F-hitung & $=80,440$ & \\
\hline & Adjusted R Square & $=$ & 0,819 & & Sig. & $=0,000$ & \\
\hline
\end{tabular}

Sumber: Data diolah, 2017

Berdasarkan Tabel 6 diatas, persamaan regresi adalah sebagai berikut:

$\mathrm{y}=\alpha+\mathrm{b} 1 \mathrm{X} 1+\mathrm{b} 2 \mathrm{X} 2+\mathrm{b} 3 \mathrm{X} 3+\mathrm{b} 4 \mathrm{X} 1 * \mathrm{X} 2+\mathrm{b} 5 \mathrm{X} 1 * \mathrm{X} 3+\varepsilon$

$=256,789+7,109 \mathrm{X} 1+0,315 \mathrm{X} 2+3,153 \mathrm{X} 3+0,012 \mathrm{X} 1 * \mathrm{X} 2+0,095 \mathrm{X} 1 * \mathrm{X} 3+\varepsilon$

Berdasarkan persamaan di atas dapat ketahui bahwa terdapat pengaruh positif variabel penggunaan teknologi informasi (X1), interaksi penggunaan teknologi informasi dengan lingkungan kerja $(\mathrm{X} 1 * \mathrm{X} 2)$ dan interaksi penggunaan teknologi informasi dengan internal locus of control $(\mathrm{X} 1 * \mathrm{X} 3)$ pada keandalan pelaporan keuangan pemerintah daerah (Y).

Dari hasil persamaan model regresi tersebut dapat disimpulkan bahwa :

1) Nilai koefisien $\mathrm{b} 4 \mathrm{X} 1 * \mathrm{X} 2=0,012$ memiliki tanda positif, ini berarti penggunaan teknologi informasi dengan dukungan lingkungan kerja yang memadai menguatkan pengaruh penggunaan teknologi informasi pada keandalan pelaporan keuangan. 
2) Nilai koefisien $\mathrm{b} 5 \mathrm{X} 1 * \mathrm{X} 3=0,095$ memiliki tanda positif, ini berarti penggunaan teknologi informasi dengan dukungan internal locus of control yang memadai menguatkan pengaruh penggunaan teknologi informasi pada keandalan pelaporan keuangan.

Besarnya nilai Adjusted $R$ Square adalah 0,819 . Hal tersebut menunjukkan bahwa variabel bebas penggunaan teknologi informasi, variabel pemoderasi lingkungan kerja dan internal locus of control berpengaruh sebesar 81,9 persen pada keandalan pelaporan keuangan pemerintah daerah, sedangkan sisanya sebesar 18,1 persen dipengaruhi oleh variabel lain yang tidak dimasukkan dalam model regresi.

Hasil analisis regresi untuk uji kelayakan model diperoleh angka probabilitas/signifikansi $0,000<0,05$, sehingga H01 dan H02 ditolak dan H1dan $\mathrm{H} 2$ diterima. Artinya, semua variabel moderasi secara simultan merupakan penjelas yang signifikan pada variabel dependen.

\section{Lingkungan Kerja Memperkuat Pengaruh Penggunaan Teknologi Informasi Pada Keandalan Pelaporan Keuangan Pemerintah Daerah}

Hasil uji hipotesis 1 yang disajikan pada Tabel 6 menunjukkan bahwa nilai koefisien beta (b4) adalah 0,012 dengan $p$-value sebesar $0,00<0,05$, menunjukan lingkungan kerja mampu memperkuat penggunaan teknologi informasi pada keandalan pelaporan keuangan pemerintah daerah, sehingga hipotesis alternatif 1 diterima. Hasil Penelitian ini menyatakan bahwa variabel lingkungan kerja mampu 
Rai Dwi Andayani W, A.A.G.P Widanaputra, dan Ida Bagus Putra Astika. Lingkungan Kerja...

memperkuat pengaruh hubungan antara penggunaan teknologi informasi pada keandalan pelaporan keuangan pemerintah daerah.

TAM menjelaskan bahwa seseorang dalam melakukan sesuatu didorong oleh dua faktor yaitu behavior beliefs dan normatif beliefs.Faktor tersebut kemudian mendorong seseorang untuk memiliki outcome evaluation dan motivation to comply.Sehingga kedua hal tersebut akan mendorong seseorang untuk berperilaku dan norma-norma pribadi. Adanya attitude dan subjective norms akan mempengaruhi perhatian/fokus seseorang dalam berberilaku. Pada akhir behavior intentionakan mempengaruhi pada perilaku seseorang. Davis et al. (1989) mengembangkan TAM untuk meneliti faktor-faktor determinan dari penggunaan sistem informasi oleh pengguna. Hasil penelitian ini menunjukan penggunaan sistem informasi dipengaruhi oleh minat pemanfaatan sistem informasi, yang mana minat tersebut dipengaruhi oleh persepsi tentang kegunaan teknologi dan persepsi tentang kemudahan penggunaan teknologi. Hal inimengindikasikan bahwa tinggi rendahnya kemampuan karyawan untukmengambil tindakan berdampak pada persepsi manfaat dari penggunaanteknologi itu dalam menghasilkan pelaporan keuangan yang andal.

Penelitian ini sejalan dengan teori atribusi yaitu untuk mengamati perilaku seseorang ditimbulkan dari faktor eksternalnya yaitu lingkungan. Perilaku yang disebabkan secara internal adalah perilaku yang diyakini berada dalam kendali pribadi dari diri individu yang bersangkutan. Perilaku secara eksternal dilihat sebagai hasil dari sebab-sebab luar yaitu terpaksa berperilaku karena situasi (Robbins, 1996). 
Suatu kenyamanan dan kelengkapan dalam bekerja yang ada di sekitar karyawan harus dipelihara sebaik mungkin agar karyawan merasa puas dalam menyelesaikan pekerjaan. Lingkungan kerja yang didasari dengan hubungan kerja yang harmonis, target yang sesuai, iklim kerja yang dinamis, fasilitas kerja yang lengkap akan sangat bermanfaat bagi kelangsungan kerja karyawan dalam bekerja (Dhermawan, 2012). Menurut Dhermawan (2012:174) lingkungan kerja harus memiliki arah tujuan yang jelas, autoritas yang memadai, target kerja yang semakin baik, komunikasi yang baik, hubungan kerja yang harmonis, peluang berkarir, dan fasilitas kerja yang lengkap. Dengan adanya harmonis dalam bekerja dan hubungan karyawan terjalin dengan baik maka tingkat manipulasi data mungkin tidak akan terjadi. Penelitian Ridolof (2014) dan Kristi (2013) juga menunjukkan bahwa lingkungan kerja sebagai variabel moderasi mampu memperkuat pengaruh penggunaan teknologi informasi pada keandalan pelaporan keuangan pemerintah daerah.

\section{Internal Locus Of Control Memperkuat Pengaruh Penggunaan Teknologi}

\section{Informasi Pada Keandalan Pelaporan Keuangan Pemerintah Daerah}

Hasil uji hipotesis 2 yang disajikan pada Tabel 6menunjukkan nilai koefisien beta (b5) sebesar 0,095 dengan $p$-value sebesar $0,000<0,05$, menunjukan internal locus of control mampu memperkuat penggunaan teknologi informasi pada keandalan pelaporan keuangan pemerintah daerah, sehingga hipotesis alternatif 2 diterima. Hasil Penelitian ini menyatakan bahwa variabel internal locus of control 
Rai Dwi Andayani W, A.A.G.P Widanaputra, dan Ida Bagus Putra Astika. Lingkungan Kerja...

mampu memperkuat pengaruh hubungan antara penggunaan teknologi informasi pada keandalan pelaporan keuangan pemerintah daerah.

Penelitian ini sejalan dengan teori TAM. Model TAM dikembangkan oleh Davis (1989), memaparkan bahwa teori ini sebagai landasan untuk memahami dan mempelajari perilaku dari pemakai teknologi dalam menerima dan menggunakan sistem informasi (Handayani, 2007). Tujuan model TAM yaitu untuk menjelaskan faktor-faktor kunci dari setiap perilaku pengguna teknologi informasi terhadap penerimaan informasi (Ferda, 2011; Seeman, 2009).

Perkembangan model TAM diharapkan akan mempermudah dalam memprediksi sikap dan penerimaan seseorang terhadap teknologi dan menyajikan informasi yang mendasar mengenai faktor-faktor yang menjadi pendorong sikap individu tersebut dalam menggunakan teknologi (Rose, 2006; Lee, 2010). Teori TAM menjelaskan bahwa setiap keinginan seseorang untuk menggunakan sistem atau teknologi ditentukan oleh dua faktor, yaitu persepsi kemanfaatan adalah tingkat kepercayaan individu bahwa penggunaan teknologi akan mampu meningkatkan kinerjanya, dan persepsi kemudahan penggunaan adalah tingkat kepercayaan individu bahwa penggunaan teknologi membuatnya lebih mudah menyelesaikan pekerjaan dengan usahanya sendiri (Venkatesh dan Davis, 2000).

Penelitian ini juga sejalan dengan teori atribusi mengenai faktor-faktor yang mengakibatkan suatu hal terjadi, apakah hal tersebut terjadi karena faktor internal atau eksternal. Teori atribusi yaitu mengenai tekanan kerja, kepuasan kerja dan 
kinerja karyawan lebih banyak dipengaruhi oleh faktor internal locus of control. Sistem pengendalian intern dapat memperkuat pengaruh internal locus of control terhadap nilai informasi laporan keuangan. Hal ini sesuai dengan teori kontinjensi yang menyatakan bahwa efektifitas strategi oleh organisasi sangat tergantung terhadap adanya ketepatan atau kesesuaian antara strategi, organisasi dan lingkungannya (Balkin dan Gomez-Mejia, 1986). Sehingga internal locus of control dapat memperkuat pengaruh penggunaan teknologi informasi pada keandalan pelaporan keuangan pemerintah daerah.Penelitian yang dilakukan oleh Pranata (2017) dan Sayputri (2017) juga menunjukkan internallocus of control mampu untuk memperkuat atau memoderasi hubungan antara penggunaan teknologi informasi pada keandalan pelaporan keuangan pemerintah daerah.

Penelitian ini masih memiliki kekurangan yaitu penelitian ini dilakukan dengan metode survei melalui kuesioner, sehingga kemungkinan karakteristik dan pendapat responden tidak tertangkap secara nyata. Oleh karena itu, untuk penelitian mendatang dapat memperluas cakupan wilayah penelitian yang lebih luas dan dikembangkan dengan menggunakan metode eksperimen atau metode kualitatif. Dengan memperhatikan dan meningkatkan lingkungan kerja yang baik, didukung dengan pemanfaatan teknologi informasi seoptimal mungkin, dan adanya rancangan pengendalian intern akuntansi yang memadai diharapkan pihak pengelola keuangan daerah khususnya bagian akuntansi mampu melaksanakan tugas dan fungsi akuntansi dengan baik akan menghasilkan laporan keuangan pemerintah daerah yang andal. 


\section{SIMPULAN DAN SARAN}

Berdasarkan hasil analisis dan pembahasan hasil penelitian, maka dapat disimpulkan bahwa bahwa semakin baik lingkungan kerja, maka akan semakin mendukung penggunaan teknologi dalam menghasilkan pelaporan keuangan yang andal dan valid. Sehingga lingkungan kerja dapat memperkuat pengaruh penggunaan teknologi informasi pada keandalan pelaporan keuangan pemerintah daerah. Sama halnya dengan semakin mereka percaya bahwa hasil dari suatu pekerjaan mereka akan lebih mudah dengan mengunakan teknologi informasi, maka pelaporan keuangan yang dihasilkan akan semakin andal.Sehingga internal locus of control dapat memperkuat pengaruh penggunaan teknologi informasi pada keandalan pelaporan keuangan pemerintah daerah.

Berdasarkan atas simpulan hasil penelitian, maka saran yang dapat diberikan adalah untuk meningkatkan penggunaan teknologi informasi di OPD Kabupaten Badung, sehingga meminimalisasi berbagai kesalahan, karena semua aktivitas pengelolaan keuangan akan tercatat secara lebih sistematis dan pada akhirnya akan mampu menyajikan laporan keuangan daerah yang andal. Diharapkan lingkungan kerja yang ada diciptakan senyaman mungkin karena lingkungan kerja yang kondusif dapat menciptakan produktivitas yang tinggi yang artinya lingkungan kerja berpengaruh terhadap kinerja karyawan. Semakin baik lingkungan kerja, maka akan semakin mendukung penggunaan teknologi dalam menghasilkan pelaporan keuangan yang andal dan valid.Diharapkan individu harus mempunyai internal locus of 
controlyang baik untuk dapat melaksanakan tugas dengan baik, karena hal tersebut dapat menghindari perilaku disfungsional. Semakin mereka percaya bahwa hasil dari suatu pekerjaan mereka akan lebih mudah dengan mengunakan teknologi informasi, maka pelaporan keuangan yg dihasilkan akan semakin andal. Berdasarkan nilai Adjusted $R$ Square, penelitian selanjutnya sebaiknya menambah variabel independen atau variabel pemoderasi lainnya seperti variabel Tri Hita Karana, karena masih ada varabel lain yang mampu mempengaruhi keandalan pelaporan keuangan pemerintah daerah.

\section{REFERENSI}

Ade, Christo. 2014. "Pengaruh Lingkungan Kerja Fisik dan Non Fisik Terhadap Kinerja Karyawan PT.Bank Mandiri (Persero) TBK. Cabang Makassar Kartini”" (skripsi). Makassar:Universitas Hasanuddin.

Anas, Khaidir. 2013. Pengaruh Kompensasi dan Lingkungan Kerja Terhadap Kepuasan Kerja Karyawan. Jurnal Jurusan Manajemen. Padang 13-14 September.

Anderson, J., Narus, J. 1990. A Model of Distributor Firm and Manufacturer Firm Working Partnerships. Journal of Marketing.

Anisatin, Nihayah. 2015. Pengaruh Sumber Daya Manusia, Pemanfaatan Teknologi Informasi, Pengendalian Internal Terhadap Ketepatwaktuan dan Keterandalan Pelaporan Keuangan Pemerintah Daerah (Studi Empiris pada DPPKAD Eks Karesidenan Pati). JurnalFakultas Ekonomi dan Bisnis Universitas Muhammadiyah Surakarta. Surakarta 10-12 September.

Arfan Ikhsan.2008. Akuntansi Sumber Daya Manusia. Yogyakarta: Graha Ilmu. p. 128-129. 
Cheng-Tsung Lu, et al. 2010. An Empirical Study of On-line Tax Filling Acceptance Model: Integrating TAM and TPB. African Journal of Business Management. African 12-13 Oktober.

Dharmawan, Yusa. 2011. "Pengaruh Kompensasi dan Lingkungan Kerja Non Fisik Terhadap Disiplin dan Kinerja Karyawan Hotel Nikki Denpasar" (tesis). Denpasar: Universitas Udayana Denpasar.

Dhermawan, Anak Agung Ngurah Bagus, I Gede Andyana Sudibya, I Wayan Mudiartha Utama. 2012. Pengaruh Motivasi, Lingkungan Kerja, Kompetensi, dan Kompensasi Terhadap Kepuasan Kerja dan Kinerja Pegawai di Lingkungan Kantor Dinas Pekerjaan Umum Provinsi Bali. Jurnal Fakultas Ekonomi Universitas Udayana. Denpasar 16-17 November.

Febriady Leonard Sembiring. 2013. Pengaruh Kualitas Sumber Daya Manusia, Pemanfaatan Teknologi Informasi dan Sistem Pengendalian Intern Terhadap Keandalan dan Ketepatwaktuan Pelaporan Keuangan Pemerintah. Jurnal Universitas Negeri Padang. Padang 29-30 Januari.

Ghozali, Imam.2009. Analisis Multivariate Dengan Program SPSS. Semarang: Universitas Diponegoro. p. 133-134.

Gita Silvia Marda. 2014. Pengaruh Sumber Daya Manusia, Pemanfaatan Teknologi Informasi dan Pengawasan Keuangan Daerah Terhadap Keandalan Pelaporan Keuangan Pemerintah Kota Dumai. Jurnal Akuntansi Fakultas Ekonomi UR. Palembang 22-23 Mei.

Gustati. 2011. "Hubungan Antara Komponen Standar Umum Aparat Pengawasan Intern Pemerintah (APIP), Motivasi, Dan Komitmen Organisasi Dengan Kinerja Auditor BPKP (Studi Pada Auditor Perwakilan Badan Pengawasan Keuangan Dan Pembangunan Provinsi Sumatera Barat)" (tesis). Padang:Universitas Andalas.

Handayani, Rini. 2007. Analisis Faktor-Faktor Yang Mempengaruhi Minat Pemanfaatan Sistem Informasi Dan Penggunaan Sistem Informasi. (Studi Empiris Pada Perusahaan Manufaktur di Bursa Efek Jakarta). Simposium Nasional Akuntansi X Makasar. Makasar 08-10 Desember.

Nor, Mohd Nazli Mohd, Smith, Malcolm and Ismail, Zubaidah. 2009. Auditors' Perception of Time Budget Preassure and Reduced Audit Quality practices:A Preliminary Study From Malaysian Context. Nigeria 28-30 Maret. 
Mahdy, Emiral and Ghozali, Imam.2012. Analisis Pengaruh Locus of Control Dan Kompleksitas Tugas Audit Terhadap Kinerja Auditor Internal (Studi pada Auditor Internal Pemerintah yang bekerja pada Inspektorat Provinsi Jawa Tengah). Jurnal Akuntansi. Yogyakarta 27-28 November.

Mudrika, Alamsyah Hasan. 2015. Pengaruh Sumber Daya Manusia, Teknologi Informasi, Pengendalian Intern Akuntansi Terhadap Keandalan dan Ketepatan Waktu Laporan Keuangan Pemerintah Kabupaten Bengkalis. Jurnal Akuntansi. Medan 22-24 Oktober.

Ridolof. 2014. Would Better Earning,Work Environment, and Promotion Opportunities Increase Employee Performance? An Investigation in State and Other Sectors in Vietnam. International Enterpreneurshirp and Management Journal. Vietnam 29-30 Desember.

Pranata, 2017. Pengaruh Kepribadian, Self Efficacy, dan Locus of Control Terhadap Persepsi Kinerja Usaha Skala Kecil dan Menengah. Jurnal Bisnis dan Ekonomi (JBE). Jakarta 14-16 November.

Rotter J.B. 1966. Genaralized Expectancies for Internal Versus External Control of Reinforcement. Pshycologycal Monographs. p. 69.

Sari, Shinta Permata dan Banu Winoto. 2014. Keterandalan dan Ketepatwaktuan Pelaporan Keuangan Daerah Ditinjau dari Sumber Daya Manusia, Pengendalian Interal dan Pemanfaatan Teknologi Informasi. Jurnal Akuntansi. Surakarta 16-19 Oktober.

Seeman, Elaine dan Shanan Gibson. 2009. Predicting Acceptance of Electronic Medical Records: Is the Technology Acceptance Model Enough? S.A.M. Advanced Management Journal. Nigeria 23-24 Maret.

Stephen P Robbins. 1996. Perilaku Organisasi, Konsep, Kontroversi dan Aplikasi. Alih Bahasa : Hadyana Pujaatmaka. Edisi Keenam. Jakarta: PT.Bhuana Ilmu Populer. p. 157-158.

Sugiyono. 2014. Metode Penelitian Bisnis. Edisi Keempat. Bandung: Alfabeta. p.117-118.

Kristi, Ferina. 2013. Pengaruh Kepemimpinan, Lingkungan Kerja Fisik, dan Kompensasi Terhadap Kinerja Karyawan di PT Pertamina (PERSERO) UPMS III Terminal Transit Utama Balongan, Indramayu. Jurnal Ekonomi \& Bisnis. Surabaya 12-13 November. 
Susilo, Prapto. 2010. "Pengaruh Pemanfaatan Teknologi Informasi, dan Pengendalian Intern Akuntansi Terhadap Keterandalan dan Ketepatwaktuan Pelaporan Keuangan Pemerintah Daerah (Studi Pada Pemerintah Kabupaten Sragen)" (tesis). Surabaya: Universitas Surabaya.

Taiwo, Akinyele Samuel. 2010. The Influence Of Work Environment On Workers Productivity : A Case Of Selected Oil and Gas Industry in Lagos, Nigeria. African Journal Business Management. Nigeria 27-28 November.

Teo, T. \& Lee C. B. 2010. Examining the Efficacy of the Theory of Planned Behavior (TPB) to Understand Pre-service Teachers' Intention To Use Technology. Journal Business Management. Singapore 12-14 November.

Venkatesh, Viswanath, Fred D. Davis. 2000. A Theoretical Extension of the Technology Acceptance Model: Four Longitudinal Field Studies. Journal Business Management. Singapore 11-13 Oktober.

Widyaningrum,Celviana. dan Rahmawati. 2010. Pengaruh SDM, dan Pemanfaatan Teknologi Informasi Terhadap Keterandalan dan Ketepatwaktuan Pelaporan Keuangan Pemerintah Daerah dengan Variable Intervening Pengendalian Intern Akuntansi, Studi Empiris di Pemda Subosukawonosraten. Simposium Nasional Akuntansi XII Purwokerto. Purwokerto 13-15 Desember.

Xiao,Li and Subhasish Dasgupta. 2002. Measurement of User Satisfaction with Web Based Information Systems: an Empirical Study. Eight Americas Conference on Information System. Singapore 27-30 September.

Yoga, Pandita Ida Bagus. 2016. Pengaruh Sifat Machiavellian, Locus of Control Internal, Dan Profesionalisme Pada Efektivitas Persetujuan Kredit di PT.Bank Negara Indonesia (Persero ), Tbk. Wilayah Denpasar. Jurnal Ekonomi dan Bisnis. Denpasar 22-23 Desember. 